\title{
Herbage production, botanical and plant-part composition of mixed black oat (Avena strigosa Scherb.) annual ryegrass (Lolium multiflorum Lam.) pastures under different management strategies
}

André Brugnara Soares ${ }^{1 *}$, André Luis Finkler da Silveira ${ }^{2}$, Tangriani Simioni Assmann ${ }^{1}$, Daniel Schmitt ${ }^{3}$

${ }^{1}$ Agronomy Department, Federal University of Technology Paraná, Campus Pato Branco, Via do Conhecimento km 01, municipality of Pato Branco, PR, Brazil

${ }^{2}$ Agronomic Institute of Paraná, Rodovia BR 158, no5.517, Brazil

${ }^{3}$ Santa Catarina State University, Avenida Camões 2090, Lages, SC, Brazil

*Corresponding author: soares@utfpr.edu.br

\begin{abstract}
Mixing annual ryegrass and black oat can improve forage production in subtropical and temperate areas with integrated croplivestock systems. Thus, we evaluated the forage production dynamics of mixed annual ryegrass-black oat pastures under different management strategies based on canopy height and supplement level. Pastures were continuously stocked with Boer goats at two grazing heights (12 or $21 \mathrm{~cm}$ ); animals received or did not receive energy supplements $\left(0\right.$ and $15 \mathrm{~g} \mathrm{~kg}^{-1}$ of body weight). These treatments were applied using a factorial scheme $(2 \times 2)$ and randomized block design with three replications. We evaluated the herbage accumulation rate ( $\mathrm{kg}$ of $\mathrm{DM} \mathrm{h}^{-1} \mathrm{day}^{-1}$ ) using the exclusion cage technique, herbage mass ( $\mathrm{HM}, \mathrm{kg}^{-} \mathrm{DM}$ ha-1) using the double sampling technique, and botanical and plant-part composition (\%) of destructive samplings. Supplementation had no effect on the parameters measured $(P \leq 0.05)$. Annual ryegrass become the predominant species during the experimental period and mainly at the lowest canopy height. Total herbage production during the 131 days of pasture utilization was $10,280 \mathrm{~kg}^{\circ} \mathrm{DM}$ ha-1. The herbage accumulation rate was similar between the two canopy heights; however, it varied throughout experimental period. Leaf lamina mass was lower in treatments $12 \mathrm{~cm}$ up to 102 after sowing; after that, they were equivalent. At the end of the study, herbage mass was $2720 \mathrm{~kg} \mathrm{DM} \mathrm{ha}^{-1}$ with the $21-\mathrm{cm}$ treatment and $2170 \mathrm{~kg} \mathrm{DM} \mathrm{ha}^{-1}$ with the $12-\mathrm{cm}$ treatment. It is recommended to maintain mixed annual ryegrass-black oat pastures at $12 \mathrm{~cm}$ in height. Reasons are discussed throughout the text.
\end{abstract}

Keywords: Avena strigosa, forage mixture, leaf mass, leaf:stem ratio, Lolium multiflorum, canopy structure.

\section{Introduction}

The climatic conditions in southwestern Paraná state, Brazil, as well as those of the rest of the southern region of the country, are highly conducive to the growth of using annual cool-season grasses. These species are good options for reducing forage shortages and feeding livestock, because they are acceptable and nutritious for grazing animals.

The recommendation to intercrop cool-season forage species such as black oat (Avena strigosa Scherb.) and annual ryegrass (Lolium multiflorum Lam.) is based on lengthening the period of pasture usage. The early growth and shorter vegetative period of black oat crops can be offset by the later production peak of ryegrass, which is known for its natural reseeding (Duchini et al., 2016; Guzatti et al., 2015) and resistance to disease. Optimization of pasture production, however, depends on both efficient grazing management and supplementation strategies. Thus, the quantity of forage available, which can be manipulated by different pasture management approaches (such as predefining grazing heights), has important effects on a pasture's botanical and structural composition. This composition, in turn, affects the foraging strategies adopted by the animals, and, consequently, their performance and efficiency in using the food resource. According to the Brazilian Institute of Geography and Statistics (IBGE, 2014), the effective herd of goats in Brazil is 9.3 millions, $2 \%$ of which are found in Paraná state (181,984 head). The limited involvement of Paraná state in terms of the number of animals produced can be explained by scarcity of studies on the management of areas grazed by goats, particularly those involving cool-season forage grasses. The adoption of appropriate practices to manage seasonal intercropped species could result in both a cheaper source of feed for animals and increased soil coverage during periods with mild temperatures. Thus, an understanding of the dynamics of the structural and botanical components of a given pasture can aid in designing adequate management strategies for the production of feed for herds. The aim of this study was to evaluate the forage production dynamics in mixed black oat 'IAPAR 61' annual ryegrass 'São Gabriel' pastures grazed by goats that received or did not receive supplements. 


\section{Results and discussion}

Supplementation did not affect any of the grazing parameters evaluated; thus, thus, the function of canopy height and period during which pastures were grazed will be presented.

\section{Grazing heights}

The use of variable stocking rates to obtain two constant canopy structures was effective (Table 1 ). This is because, during the experimental periods, there was a difference between high and low grazing heights $(P \leq 0.05)$. The data obtained shows that pasture management based on planned canopy heights was adequate. In every period, the intended heights of $12 \mathrm{~cm}$ and $21 \mathrm{~cm}$ were, in fact, different, and there was no difference between periods with different grazing intensities; thus, a coefficient of variation of $13.5 \%$ was obtained for canopy heights.

Pasture management through controlled canopy height is a simple and reliable way to use farmland because it has a direct relationship with herbage mass and canopy structure. These relationships were confirmed by Aguinaga et al. (2008), who found increases of 86.3 and $130 \mathrm{~kg}$ of dry mass (DM) $\mathrm{cm}^{-1}$ of height, respectively. In a study of black oat and annual ryegrass pastures, Carvalho et al. (2010) found that, for each centimeter of canopy height, there was an increase of approximately $108 \mathrm{~kg}$ of $\mathrm{DM} \mathrm{ha-1}$. Another finding regarding canopy height was that goats grazed in a relatively uniform way. The treatments in this study were similar at both heights; therefore, no areas were overgrazed or undergrazed.

\section{Herbage mass and plant-part composition}

There was interaction between sward height and experimental period $(P \leq 0.05)$ in determining herbage mass (Table 2). Herbage mass differed by grazing height only during the second (75-102 days after sowing [DAS]) and third (103-130 DAS) periods. Because herbage mass was not a management criterion, it was associated with greater height variation: its coefficient of variation was $24.0 \%$. Both the differences in herbage mass and the effect of grazing intensity could be attributed to variation in the botanical and structural composition of the pastures (Figure 2), as well as to possible changes in pasture bulk density, because one of the management criteria was to maintain relatively constant canopy heights. At $21 \mathrm{~cm}$ height, greater herbage mass may have been the result of black oat accumulation at the end of the vegetative cycle or the result of greater elongation of internodes, which increase the percentage of DM (Duchini et al., 2016).

Bremm et al. (2005), evaluating the intercropping of black oat and annual ryegrass with different amounts of supplementation, found the following herbage masses (measured in $\mathrm{kg}$ of DM ha-1) and pasture heights (measured in $\mathrm{cm}$ ) in their four experimental periods: 977 and 16; 1112 and 12; 1360 and 15; 1590 and 16, respectively. Similar values were found with low height canopies in the first four experimental periods (up to 158 DAS) in the current study. For annual ryegrass grazed by lambs, Pontes et al. (2004) recommended canopy heights of approximately $12 \mathrm{~cm}$. These authors also reported that optimization of biomass flows takes place when pastures are maintained between $10-15 \mathrm{~cm}$ height. This is also the range in which lambs showed the greatest gains in daily weight and the greatest gains per hectare. Roman et al. (2007), however, reported that herbage mass between 1,100 and $1,800 \mathrm{~kg}$ of $\mathrm{DM} \mathrm{ha}^{-1}$ did not limit herbage intake and resulted in the same live weight gain per hectare, with similar efficiency in transforming forage into animal product. Similarly, Mott (1984) showed that the availability of forage required for maximal performance of temperate forage species is between 1,200 and $1,600 \mathrm{~kg} \mathrm{ha}^{-1}$ of DM.

The herbage mass quantities found in the last experimental period (159-187 DAS) at both the lower height $(2,170 \mathrm{~kg}$ of $\left.\mathrm{DM} \mathrm{ha}{ }^{-1}\right)$ and the greater height $(2,720 \mathrm{~kg}$ of DM ha-1) were above the management recommendations of Assmann et al. (2003) for crop-livestock systems in clay soils. These authors recommended a constant of approximately $2,000 \mathrm{~kg} \mathrm{ha}^{-1}$ of cover crop biomass for no-till systems. In contrast, the values found in our study were lower $\left(3,800 \mathrm{~kg}\right.$ of $\left.\mathrm{DM} \mathrm{ha}^{-1}\right)$ than those recommended by Wesp et al. (2016) to overcome the effect of animal trampling on soil physical characteristics. The greatest herbage mass in the final period (159-187 DAS) of pasture usage was the result of the prolonged vegetative cycle of these species; however, this was associated with an increase in the stem and dead material proportions (Figure 3). If pasture management is considered in a crop-livestock integration system, the increase in herbage mass from September is very convenient for maintaining the minimum amount of cover biomass in no-tillage systems.

There was an interaction between canopy height and experimental period $(P \leq 0.05)$ in terms of the leaf lamina mass of both black oat and ryegrass, as shown in Figure 2A. In the initial periods of pasture usage (up to 130 DAS), higher leaf blade mass values were observed with the higher canopy height. Because different structures were formed with the two treatments, the lower herbage mass and effect of grazing may have led to the reduced amount of leaf blades in these periods. Both the "high" and "low" canopy heights resulted in larger leaf blade masses in August (the third experimental period; 103-130 DAS), as shown in Figure $2 \mathrm{~B}$. This pattern may be the consequence of greater forage accumulation than that in the first grazing period (54-74 DAS; Figure 1), which coincided with increased ryegrass in the herbage mass. During that period (which was the middle of the vegetative stage), the plants mostly produced leaf blades, which explains the increased quantity observed.

The contribution of leaf lamina to forage mass is important because it affects the nutritive value of the forage. Because leaf lamina are the most nutritious component of the grasses and also the one that animals most frequently choose when grazing, they should receive more attention than total herbage production. Animal intake and production are more correlated with the amount of dry leaf mass than total forage mass (Sollenberger and Burns, 2001). There was an interaction between sward height and experimental period $(P \leq 0.05)$ in terms of the stem mass of black oat grass (with a coefficient of variation of $38.3 \%$ ) and ryegrass (with a coefficient of variation of $58.7 \%$ ), as shown in Figure 3. In the second (75-102 DAS) and third (75-102 DAS) periods, there was a greater stem mass with greater sward height (Figure 3A). A greater pasture height increased elongation of internodes (mainly from black oat), which 
Table 1. Average canopy height $(\mathrm{cm})$ registered throughout the experimental period in mixed black oat - annual ryegrass pastures maintained at two canopy heights by continuous stocking method.

\begin{tabular}{lcc}
\hline \multirow{2}{*}{ Days after sowing } & \multicolumn{2}{c}{ Canopy height } \\
\cline { 2 - 3 } & High $(21 \mathrm{~cm})$ & Low $(12 \mathrm{~cm})$ \\
\hline $54-74$ & $22 \mathrm{Ab}$ & $15 \mathrm{Aa}$ \\
$75-102$ & $24 \mathrm{Ab}$ & $13 \mathrm{Aa}$ \\
$103-130$ & $23 \mathrm{Ab}$ & $12 \mathrm{Aa}$ \\
$131-158$ & $20 \mathrm{Ab}$ & $12 \mathrm{Aa}$ \\
$159-187$ & $17 \mathrm{Ab}$ & $9 \mathrm{Aa}$ \\
\hline Mean & 21 & 12 \\
\hline Coef. of variation & & \\
\hline Averages followed by the same uppercase letter in the column and the lowercase letter in the row did not differ from each other according to the Tukey test when $\alpha<0.05$.
\end{tabular}

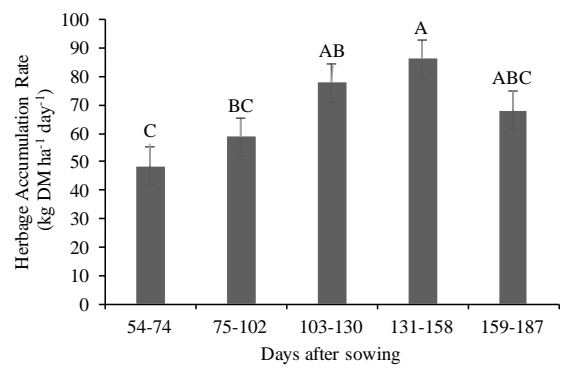

Fig 1. Herbage accumulation rate $\left(\mathrm{kg} \mathrm{DM} \mathrm{ha}^{-1} \mathrm{day}^{-1}\right)$ registered throughout the experimental in mixed black oat - annual ryegrass pastures maintained at two canopy heights by continuous stocking method. Vertical lines represent the standard error of the mean (SEM).

Table 2. Herbage mass ( $\mathrm{kg} \mathrm{DM} \mathrm{ha}^{-1}$ ) registered throughout the experimental period in mixed black oat - annual ryegrass pastures maintained at two canopy heights by continuous stocking method.

\begin{tabular}{lcc}
\hline \multirow{2}{*}{ Days after sowing } & \multicolumn{2}{c}{ Canopy height } \\
\cline { 2 - 3 } & High $(21 \mathrm{~cm})$ & Low $(12 \mathrm{~cm})$ \\
\hline $54-74$ & $1520 \mathrm{Ca}$ & $900 \mathrm{Ba}$ \\
$103-102$ & $1950 \mathrm{ABCa}$ & $1010 \mathrm{Bb}$ \\
$131-158$ & $2540 \mathrm{ABa}$ & $1400 \mathrm{Bb}$ \\
$159-187$ & $1870 \mathrm{BCa}$ & $1530 \mathrm{ABa}$ \\
\hline Mean & $2720 \mathrm{Aa}$ & $2170 \mathrm{Aa}$ \\
\hline Coef. of variation & 2120 & 1400 \\
\hline \multicolumn{2}{l}{ Means followed by the same uppercase letter in the column and the lowercase letter in the row did not differ from each other according to the Tukey test when $\alpha<0.05}$.
\end{tabular}
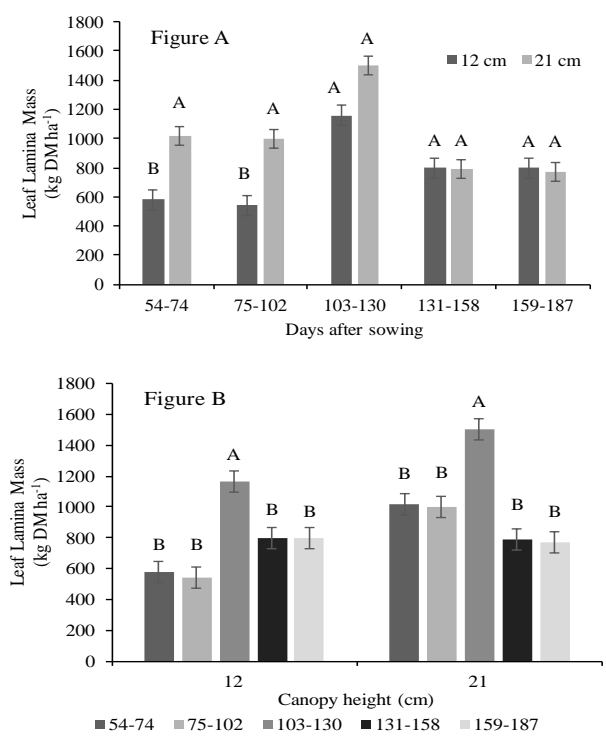

Fig 2. Leaf blade mass ( $k g$ of $D M h^{-1}$ ) registered throughout the experimental in mixed black oat - annual ryegrass pastures maintained at two canopy heights by continuous stocking method. Different uppercase letters within each period (A) or at each sward height (B) differ according to the Tukey test when $p \leq 0.05$. Vertical lines represent the standard error of the mean (SEM). 

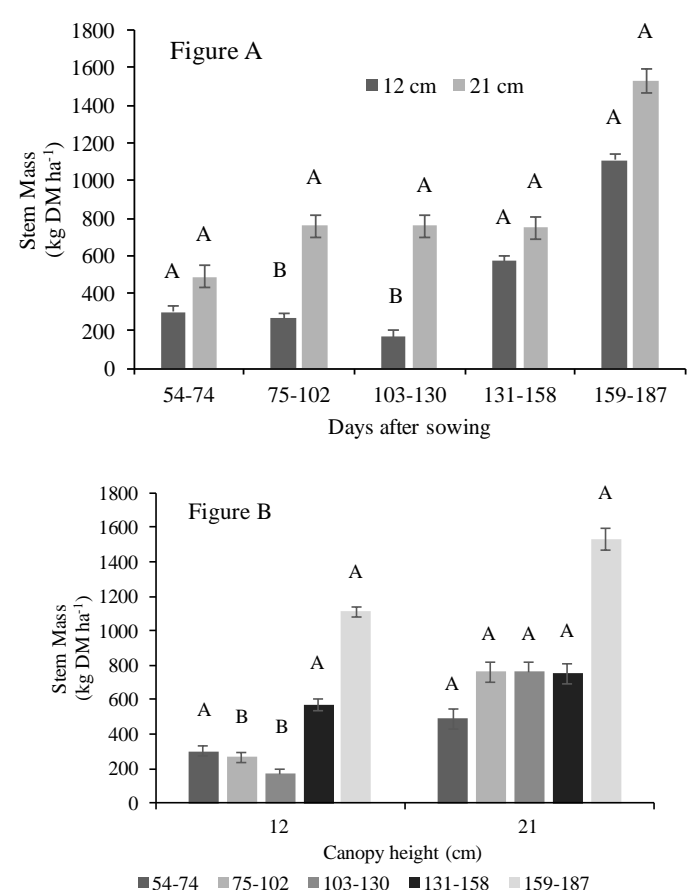

Fig 3. Stem mass $\left(\mathrm{kg}_{\mathrm{g}}\right.$ of $\mathrm{DM} \mathrm{ha} \mathrm{a}^{-1}$ ) registered throughout the experimental in mixed black oat - annual ryegrass pastures maintained at two canopy heights by continuous stocking method. Different uppercase letters within each period (A) or at each sward height (B) differ according to the Tukey test when $p \leq 0.05$. Vertical lines represent the standard error of the mean (SEM).
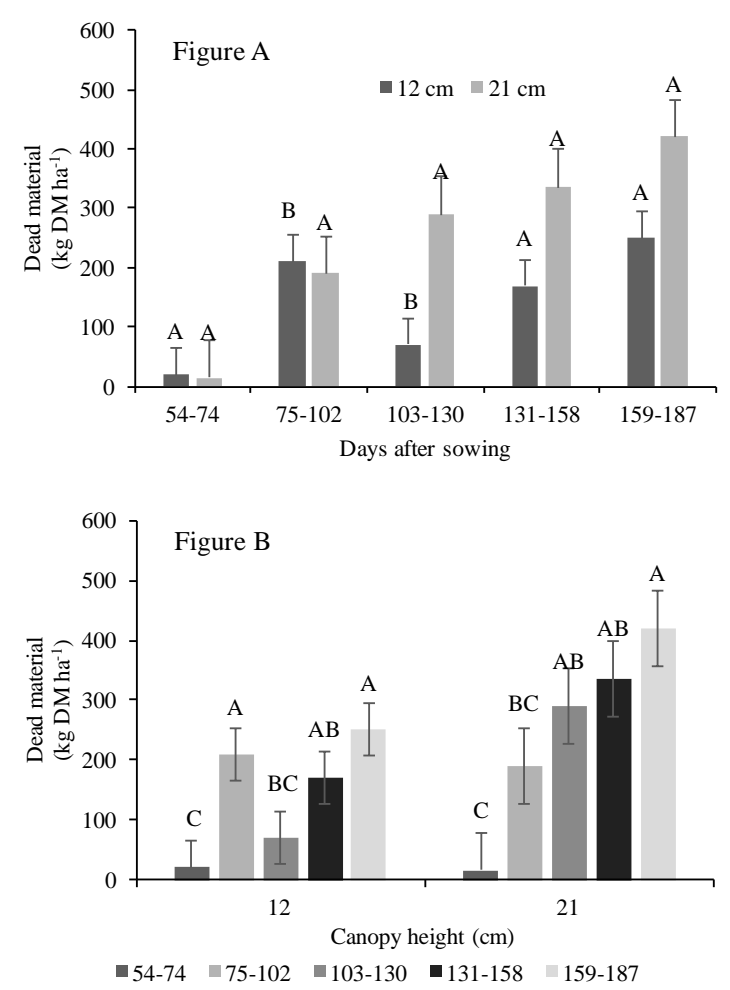

Fig 4. Dead material ( $\mathrm{kg}$ of $\mathrm{DM} \mathrm{ha}^{-1}$ ) registered throughout the experimental in mixed black oat - annual ryegrass pastures maintained at two canopy heights by continuous stocking method. Different uppercase letters within each period (A) or at each sward height (B) differ according to the Tukey test when $p \leq 0.05$. Vertical lines represent the standard error of the mean (SEM).

resulted in more stem mass than observed with the lower sward height. Both the "high" and "low" canopy heights were associated with greater stem masses in the last experimental period (159-187 DAS; Figure 3B): the quantities were $1,530 \mathrm{~kg} \mathrm{ha}^{-1}$ and $1,110 \mathrm{~kg} \mathrm{ha}^{-1}$, respectively. A higher proportion of stems during this period, which was independent of the canopy height, represented the end of the plant cycle. According to Dove (1998), plant aging leads to a decreasing leaf proportion and an increasing stem and inflorescence proportion. The amount of stems relative to 
leaf blades has important effects on grazing and selectivity by animals. Animals select their forage structures based on the ease of chewing and ingestion, and they prefer forage that can be ingested more quickly (Kenney and Black, 1984). The ease that animals experience during prehension depends on canopy structure and elongation of internodes (Carvalho, 2013). In addition, increasing stems and decreasing the leaf:stem ratio generally decreases forage bulk density (Sollenberger and Burns, 2001). The height of the stem/pseudo-stem layer may represent a barrier for greater depth of bite into the canopy level (Fonseca et al., 2012; Mezzalira et al., 2014). After comparing goat preferences, Bratti et al. (2009) reported that animals spent more time grazing in areas with a greater leaf:stem ratio. In our study, the average leaf:stem ratio was about 1:4-1.3. When one considers the goats' preference for more leaf blades, it is likely that, at the lower canopy height, the canopy structure was more appropriate for grazing.

There was an interaction between canopy height and the experimental periods $(P \leq 0.05)$ in terms of dead material from oat grass and ryegrass (Figure 4). There was a difference between the two canopy heights only in August (103-130 DAS; $P \leq 0.05)$. This difference was likely due to the greater proportion of black oat in the herbage mass when the pasture height was kept at $21 \mathrm{~cm}$. Because black oat finishes its production cycle prior to ryegrass, a greater accumulation of dead material in the pasture can be expected.

Thus, the greater canopy height allowed the animals to select specific plant parts and species. This selection can contribute to a greater accumulation of dead material because forage harvest efficiency is less with greater canopy heights (Silva et al., 2016). When pastures are less intensely defoliated, forage plants eliminate leaf blades from the lower strata because the blades result in a negative carbon balance (Parsons et al., 1988; Chapman 2016). Grant et al. (1981) found higher rates of leaf senescence in plots with greater canopy heights, and they reported a greater proportion of mature or senescent tissues, as well as reduced light penetration, in pastures with higher canopies. When considering all of the experimental periods, the amount of dead material was higher in the last period (159187 DAS) than the first period (54-74 DAS) at both the 21-cm height and the $12-\mathrm{cm}$ height ( $P \leq 0.05$; Figure $4 B$ ). Thus, there was an increase in the proportion of dead material over the period of pasture use a phenomenon that is a natural consequence of the plant cycle.

\section{Daily herbage accumulation}

The daily herbage accumulation rate was similar between the two canopy heights. The coefficient of variation obtained for this variable was $29.5 \%$. A similarity in accumulation rates between grazing heights has also been found by other researchers working with mixed pastures (Aguinaga et al., 2008; Carvalho et al., 2010). Herbage accumulation at the lower sward height may be favorable because of the greater proportion of ryegrass, which is a species that is both highly tolerant of grazing (Young et al., 1996) and highly productive (Duchini et al., 2016). Even at a higher grazing intensity (12 $\mathrm{cm})$, ryegrass is able to maintain a good leaf area close to the soil, in a way that stimulates plant regrowth. The daily herbage accumulation rate varied from 48 to $86 \mathrm{~kg} \mathrm{ha}^{-1}$ day-
1 , with an average of $60.4 \mathrm{~kg}$ of DM ha-1 $\mathrm{day}^{-1}$. These values are close to those described Duchini et al 2016.

The effect of experimental period on accumulation rate $(P \leq$ $0.05)$ can be seen in Figure 1 . The highest accumulation rate occurred in September (103-130 DAS), and this rate differed significantly only from those associated with the two first experimental periods $(P \leq 0.05)$. The similarity between the growth curves of each species may explain these results. It is possible that the greater accumulation in the third experimental period (103-130 DAS) resulted from the peak in ryegrass growth. This conclusion is consistent with the changing botanical composition of the pasture, which is an advantage of intercropping these two forage species. The pastures presented different percentages of black oat and ryegrass at $21 \mathrm{~cm}$ in height: values of $91 \%$ and $7 \% ; 76 \%$ and $15 \% ; 65 \%$ and $23 \%$; $39 \%$ and $44 \%$, and $0 \%$ and $84 \%$ of black oat grass and rye grass, respectively, were recorded on the different evaluation dates. Meanwhile, at a height of $12 \mathrm{~cm}$, the percentages of black oat grass and ryegrass in each period were $96 \%$ and $3 \% ; 54 \%$ and $25 \% ; 28 \%$ and $67 \% ; 12 \%$ and $77 \%$; and $0 \%$ and $88 \%$, respectively. These values show that, with the lower canopy height, the role of ryegrass was already evident in the second experimental period (75-102 DAS), and that it was the dominant crop beginning the third period (103-130 DAS). The same result was not found at the greater canopy height. Therefore, in mixed black oatryegrass pastures, a $12-\mathrm{cm}$ height is better because it allows for ryegrass to contribute to herbage mass sooner. High forage accumulation rates within a short period of time allow for the large accumulation of dry material, which needs to be consumed to prevent significant losses in quality and may result in a canopy that is unfit for animal consumption.

Total forage production during the entire experimental period (131 days) was $10,280 \mathrm{~kg}$ of $\mathrm{DM} \mathrm{ha}^{-1}$. This value demonstrates the potential of intercropping black oat and ryegrass in highly fertile soils and using nitrogen fertilization. Aguinaga et al. (2008) obtained $10,721 \mathrm{~kg}$ of $\mathrm{DM} \mathrm{ha}^{-1}$ in mixed black oat-annual ryegrass pastures. In terms of croplivestock systems, the production levels observed in this experiment show that there can be high production of forage for animals with an appropriate amount of residual biomass to maintain a no-tillage system.

\section{Materials and methods}

\section{Site and pasture establishment}

This experiment was performed from April to October 2009 at the Agricultural Research Institute of Paraná State in Pato Branco, Paraná, Brazil (2607' South; 5239' West). The soil at this site is classified as rhodic ferralosol rich in clay (Soil Survey Staff, 2006) with the following chemical characteristics: $P=12.9 \mathrm{mg} \mathrm{dm}{ }^{-3}$, organic matter $=59.0 \mathrm{~g}$ $\mathrm{dm}^{-3}, \mathrm{pH}=4.9$ in $\mathrm{CaCl}_{2}, \mathrm{Ca}=5.7 \mathrm{cmolc} \mathrm{dcm}^{-3}, \mathrm{Mg}=2.6 \mathrm{cmolc}$

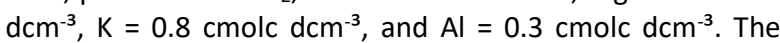
local climate reflects the transition between humid and subtropical Cfa and Cfb climates, according to the Köppen classification system (Alvares et al., 2014). Meteorological data was registered by the IAPAR-Pato Branco Station. The average monthly temperature during the experiment was $16.3^{\circ} \mathrm{C}$ and average monthly rainfall was $170.4 \mathrm{~mm}$. Rainfall was distributed well throughout the experiment. The lowest 
temperature registered was $-1.9^{\circ} \mathrm{C}$, which occurred on July 25 (92 DAS), whereas the highest temperatures $\left(30.2^{\circ} \mathrm{C}\right.$ and $30.3^{\circ} \mathrm{C}$ ) occurred on October 4 and 5 (163-164 DAS), respectively.

Annual ryegrass was broadcast seeded on April 24 using 27 $\mathrm{kg}$ of seeds per hectare. This was followed by fertilization and black oat seeding by sower machine with $17 \mathrm{~cm}$ between rows and a density of $55 \mathrm{~kg}$ of seeds per hectare. Fertilizer was applied at $200 \mathrm{~kg} / \mathrm{ha}$ using the 10-30-10 formula ( $20 \mathrm{~kg}$ of N ha-1, $60 \mathrm{~kg}^{-}$of $\mathrm{P}_{2} \mathrm{O}_{5} \mathrm{ha}^{-1}$, and $20 \mathrm{~kg}$ of $\mathrm{K}_{2} \mathrm{O}$ $\left.\mathrm{ha}^{-1}\right)$. Nitrogen fertilizer was applied three times manually, at $50 \mathrm{~kg}$ of $\mathrm{N} / \mathrm{ha}$ each time. The pasture was first used on June 17, 2009, which was 54 DAS, and it presented an average herbage mass of $1054.8 \mathrm{~kg}$ of DM ha-1. The grazing period was 131 days, covering five experimental periods and lasting until October 30, 2009. For the herbage analyses, samples were collected on the following dates: June 17 (54 DAS), July 8 (75 DAS), August 5 (103 DAS), September 2 (131 DAS), September 30 (159 DAS), and October 28 (187 DAS). The interval between the first two dates was 21 days and was 28 days between all of the other dates.

\section{Treatments and experimental design}

The experimental design was a randomized block design with four treatments and three replications. Treatments were the combination in factorial scheme $(2 \times 2)$ between two canopy heights $(12$ and $21 \mathrm{~cm})$ and two amounts of energetic supplements ( 0 and $15 \mathrm{~g} \mathrm{~kg}^{-1}$ of body weight). Each paddock (replication) was grazed by three Boer goats (Capra aegagrus), plus a variable number of put-and-take animals to maintain canopy height targets. The stocking method was continuous with a variable stocking rate that was adjusted according to the put-and-take technique (Mott and Lucas, 1952 ) to maintain canopy height targets. The canopy heights were monitored weekly with a sward stick (Bartham, 1985) in 35 random points per plot. The animals had unlimited access to water and mineral supplements. The animals that received supplements were fed half of the feed (ground corn) at 8:30am and the other half at $4: 00 \mathrm{pm}$ on a daily basis. They received a total of $15 \mathrm{~g} \mathrm{~kg}^{-1} \mathrm{day}^{-1}$ of body weight of these supplements.

\section{Analyzed variables}

The herbage accumulation rate ( $\mathrm{kg}$ of $\mathrm{DM} \mathrm{h}^{-1}$ day $^{-1}$ ) was estimated using the technique described by Campbell (1966). Before the animals were allowed into the pasture, three grazing exclusion cages were placed in areas that represented the herbage mass of each plot. The herbage mass (HM, kg of DM ha-1) was evaluated every 21 or 28 days (depending on the period) using the double sampling technique (Haydock and Shaw, 1975). The total production of dry material ( $\mathrm{kg}$ of DM ha-1) was calculated as the sum of herbage production observed over the course of the experimental periods (herbage accumulation rate $*$ number of days in the period) plus the initial herbage mass. The botanical and structural composition of the pasture ( $\mathrm{kg}$ of $\mathrm{DM} \mathrm{ha}{ }^{-1}$ ) was estimated after manual separation of the leaf lamina and stem components from the oat and ryegrass. The estimation also considered the dead material from the three forage samples taken from each plot; these samples were collected from $0.051 \mathrm{~m}^{2}$ areas. The samples were weighed and pre-dried in an oven with natural convection at 55ㅇ $\mathrm{C}$ for 72 hours until a constant weight was reached.

\section{Data analysis}

After the assumptions of normality and homogeneity of variances were satisfied, an analysis of variance was applied to the data using a general linear model (GLM) procedure and a Pearson correlation coefficient. To compare the effects of treatments, the Tukey test was conducted with an $\alpha$-value of 0.05 in SAS statistical software (1999) using the GLM procedure. The general model used in the analysis of variables is represented by the following: $Y_{i j k l}=\mu+\beta_{i}+A_{j}+$ $S_{k}+(A S)_{j k}+(B A S)_{i j k}+\gamma_{l}+(A \gamma)_{j l}+(S \gamma)_{k l}+(A S \gamma)_{j k l}+\varepsilon_{i j k l}$, where $Y_{\mathrm{ijkl}}$ represents the possible answers; $\mu$ is an average of all of the observations; $\beta_{i}$ is the effect of block $i ; A_{j}$ is the effect of height $j$ in the pasture; $S_{k}$ is the effect of amount $k$ of the supplement; $(A S)_{j k}$ represents the interaction between the height $j$ and amount $k$ of the supplement; $(\beta A S)_{i j k}$ is a random effect due to the interaction between block $i$, height $j$, and amount $k$ of the supplement (error $a) ; \gamma_{1}$ is the effect of period I observed (period); $(A Y)_{j 1}$ is the effect of the interaction between the height $j$ and period $I ;(S Y)_{k l}$ is the effect of the interaction between amount $k$ of the supplement and period $l ;(A S Y)_{j k l}$ is the effect of the interaction between height $j$, amount $k$ of the supplement, and period $l$; and $\varepsilon_{i \mathrm{ijk}}$ represents random, assumed independent, and normally distributed error (error b).

\section{Conclusion}

In pastures with intercropped black oat grass and ryegrass that is grazed by goats, it is recommended to maintain canopy height around $12-\mathrm{cm}$ for the early development of ryegrass. This height makes it possible to take advantage of ryegrass's production potential in intercropping during pasture use. Similarly, this lower canopy height creates canopy conditions that are more conducive to grazing by goats. The structure of the canopy changes according to sward height and growth cycle of the species and varies over the period of pasture use. These changes result in an increase in stem mass and dead material at the end of each cycle.

\section{References}

Aguinaga $A A Q$, Carvalho PCF, Anghinoni I, Pilau A, Aguinaga AJQ, Gianluppi GDF (2008) Componentes morfológicos e produção de forragem de pastagem de aveia e azevém manejadas em diferentes alturas. $\mathrm{R}$ Bras Zootec. 37:15231530.

Alvares CA, Stape JL, Sentelhas JLMG, Sparovek G (2014) Köppen's climate classification map for Brazil. Meteorol Z. 22:711-728.

Assmann TS, Ronzelli JP, Moraes A, Assmann AL, Koehler HS, Sandini I (2003) Rendimento de milho em área de integração lavoura-pecuária sob o sistema de plantio direto, em presença e ausência de trevo branco, pastejo e nitrogênio. Rev Bras Ciênci Solo. 27:675-683.

Bartham GT (1985) Experimental techniques: The HFRO sward stick. HFRO Biennial Rep. 1984-1985. Hill Farming Research Organization, Penicuik, Midlothian, UK. 
Bratti LFS, Dittrich JR, Barros CS, Silva CJA, Monteiro ALG, Rocha C, Rocha FMP (2009) Comportamento ingestivo de caprinos em pastagem de azevém e aveia-preta em cultivo puro e consorciado. Ci Anim Bras. 10:397-405.

Bremm C, Rocha MG, Restle J, Pilau A, Montagner DB, Freitas FK, Macari S, Elejalde DAG, Roso D, Roman J, Guterres EP, Costa VG, Neves FP (2005) Efeito de níveis de suplementação sobre o comportamento ingestivo de bezerras em pastagem de aveia (Avena strigosa Schreb.) e azevém (Lolium multiflorum Lam.). R Bras Zootec. 34:387397.

Campbell AG (1966) Grazed pastures parameters: I. Pasture dry matter production and availability in a stocking rate and grazing management experiment with dairy cows. J Agric Sci. 67:211-216.

Carvalho PCF (2013) Harry Stobbs memorial lecture: can grazing behavior support innovations in grassland management? Trop Grass - Forrajes Trop. 1:137-155.

Carvalho PCF, Rocha LM, Baggio C, Macari S, Kunrath TR, Moraes A (2010) Característica produtiva e estrutural de pastos mistos de aveia e azevém manejados em quatro alturas sob lotação contínua. R Bras Zootec. 39:1857-1865.

Chapaman (2016) Using ecophysiology to improve farm efficiency: application in temperate dairy grazing systems. Agiculture. 6:1-19.

Dove $H$ (1998) The ruminant, the rumen and the pasture resourse: nutrient interactions in the grazing animal. In: Hodgson, J.; Illius, W (eds.) The ecology and management of grazing systems, CAB International, London.

Duchini PG, Guzatti GC, Ribeiro-Filho HMN, Sbrissia AF (2016) Intercropping black oat (Avena strigosa) and annual ryegrass (Lolium multiflorum) can increase pasture leaf production compared with their monocultures. Crop Pasture Sci. 67:574-581.

Soil Survey Staff (2006) Keys to soil taxonomy, 10th edn, U.S. Department of Agriculture Handbook, Washington.

Fonseca L, Mezzalira JC, Bremm C, Filho RSA, Gonda HL, Carvalho PCF (2012) Management targets for maximising the short-term herbage intake rate of cattle grazing in Sorghum bicolor. Livest Sci. 145:205-211.

Grant SA, Barthram GT, Torvell L (1981) Components of regrowth in grazed and cut Lolium multiflorum swards. Grass Forage Sci. 36:155-168.

Guzatti GC, Duchini PG, Sbrissia AF, Ribeiro-Filho HMN (2015) Aspectos qualitativos e produção de biomassa em pastos de aveia e azevém cultivados puros ou consorciados e submetidos a pastejo leniente. Arq Bras Med Vet Zootec. 67:1399-1407.

Haydock KP, Shaw NH (1975) The comparative yield method for estimating dry matter yield of pasture. Aust J Agric Anim Husb. 15:66-70.
IBGE. 2014. Instituto Brasileiro de Geografia e Estatística. http://www.ibge.gov.br/home/estatistica/economia/ppm/ 2010/ppm2010.pdf (accessed on 24/09/2014).

Kenney PA, Black JL (1984) Factors affecting diet selection by sheep. I Potential intake rate and acceptability of feed. Aust J Agric Res. 35:551-563.

Mezzalira JC, Carvalho PCF, Fonseca L, Bremm C, Cangiano C, Gonda HL, Laca EA (2014) Behavioural mechanisms of intake rate by heifers grazing swards of contrasting structures. Appl Anim Behav Sci. 153:1-9.

Mott GO, Lucas HL (1952) The design, conduct and interpretation of grazing trials on cultivated and improved pastures. p.1380. In.: Proceedings of the 60 International Grassland. Congress.

Mott GO (1984). Relationship of available forage and animal performance in tropical grazing systems. p.373-377. In: Proceedings of Forage and grassland conference, Houston.

Parsons AJ, Johnson IR, Harvey A (1988) Use of a model to optimize the interaction between frequency and severity of intermittent defoliation and to provide a fundamental comparison of the continuous and intermittent defoliation of grass. Grass Forage Sci. 43:49-59.

Pontes LS, Carvalho PCF, Nabinger C, Soares AB (2004) Fluxo de biomassa em pastagem de azevém anual (Lollium multiflorum Lam) manejada em diferentes alturas R Bras Zootec. 33:529-537.

Roman J, Rocha MG, Pires CC, Elejalde DG, Kloss MG, Neto RAD (2007) Comportamento ingestivo e desempenho de ovinos em pastagem de azevém anual (Lolium multiflorum Lam.) com diferentes massas de forragem. $\mathrm{R}$ Bras Zootec. 36:780-788.

Young WC, Chilcote DO, Yougberd HW (1996) Annual ryegrass seed yield response to grazing during early stem elongation. Agron J. 88:211-215.

SAS INSTITUTE. SAS/STAT User's guide, Version 8. Cary, NC: SAS Institute, 1999.

Silva VJ, Pedreira CGS, Sollenberger LE, Silva LS, Yasuoka JI, Almeida CL (2016) Canopy height and nitrogen affect herbage accumulation, nutritive value, and grazing efficiency of 'Mulato II' brachiariagrass. Crop Sci. 56:20542061.

Soil Survey Staff (2006) Keys to soil taxonomy, 10th edn. Washington, DC: U.S. Department of Agriculture Handbook.

Sollenberger LE, Burns JC (2001) Canopy characteristics, ingestivo behavior and herbage intake in cultivated tropical grasslands. p.321-327. In: Proceedings of 19o International Grassland Congress. São Paulo.

Wesp CL, Carvallho PCF, Conte O, Cadenazzi M, Anghinoni I, Bremm C (2016) Steers production in integrated croplivestock systems: pasture management under different swards heights. Rev Ciênci Agron. 47:187-194. 